\title{
Cervical Cancer cM0 TNM Finding v7
}

National Cancer Institute

\section{Source}

National Cancer Institute. Cervical Cancer CMO TNM Finding v7. NCI Thesaurus. Code C89501.

Cervical cancer in which there is no evidence of distant metastasis. (from AJCC 7th Ed.) 